НАУКОВИЙ ВІСНИК

Scientific messengerer of Livi National University of
Veterinary Medicine and Biotechnologies

(1)

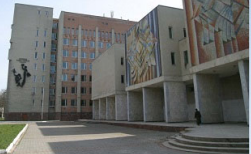

СЕРЯ: ВЕтЕРинаРнН НАУКИ
Науковий вісник Дьвівського націонадьного університету ветеринарної медицини та біотехнодогій імені С.3. Гжицького. Серія: Ветеринарні науки

Scientific Messenger of Lviv National University of Veterinary Medicine and Biotechnologies. Series: Veterinary sciences

UDC 636.4.09:616.155.194-08

\title{
Comparative effectiveness of iron-containing drugs for the prevention of iron deficiency anemia in piglets
}

I. M. Derkach

National University of Life and Environmental Sciences of Ukraine, Kyiv, Ukraine

Article info

Received 18.03.2021

Received in revised form 22.04.2021

Accepted 23.04.2021

The National University of Life and Environmental Sciences of

Ukraine, Heroyiv Oborony Str., 15 , Kyiv, 03041, Ukraine.

Tel.: +38-066-772-41-94

E-mail: irina1215@ukr.net
Derkach, I. M. (2021). Comparative effectiveness of iron-containing drugs for the prevention of iron deficiency anemia in piglets. Scientific Messenger of Lviv National University of Veterinary Medicine and Biotechnologies. Series: Veterinary sciences, 23(102), 66-71. doi: $10.32718 /$ nvlvet10210

Prevention of iron deficiency anemia in piglets is an important preventive measure to ensure the health of pigs, as mortality from this pathology is quite high, and animals that recover from treatment do not realize their own potential productivity. The aim of our study was to evaluate the effectiveness of the use of iron (IV) clatrochelate in combination with cyanocobalamin for the prevention of iron deficiency anemia in piglets compared to the traditional scheme of prevention of this disease. To achieve this goal, 2 groups of newborn piglets-analogues were formed during their retention with suckling sows - control and experimental, 15 animals in each. The experiment lasted 30 days. Piglets in the experimental group were selected from sows given $10 \mathrm{ml}$ of $10 \%$ iron (IV) clatrochelate solution and cyanocobalamin solution twice intramuscularly during pregnancy. Piglets of the control group according to the traditional scheme of prevention of iron deficiency anemia on the second day of life were administered iron dextran drug (at the rate of $200 \mathrm{mg}$ of iron (III) per injection). The results of the study show that the body weight of piglets from 1 to 9 days of their life who are born from sows which used iron (IV) clatrochelate and cyanocobalamin during pregnancy was less $(P<0.001)$ than the body weight of piglets which used iron dextran on the 2nd day after birth; did not differ on the 12 day of life, but on the 30 day was higher than the body weight of piglets in the control group 1.15 times $(P<0.001)$. The level of protein in the serum of piglets of the experimental group from birth to 30 day of life was probably higher compared to the control, which indicates that iron (IV) clatrochelate stimulates protein synthesis in the body. Therefore, double injection of $10 \%$ solution of iron (IV) clatrochelate in a dose of $10 \mathrm{ml}$ in combination with injections of cyanocobalamin at a dose of $500 \mathrm{mcg}$ of active substance to pregnant sows pregnant sows 14 and 7 days before the expected farrowing provides a preventive effect of iron deficiency anemia in piglets born to them.

Key words: iron, clatrochelate, anemia, piglets, sows, weigh, protein.

\section{Порівняльна ефективність ферумовмісних лікарських засобів профілактики ферумдефіцитної анемії поросят}

\author{
I. М. Деркач
}

Національний університет біоресурсів і природокористування Украӥни, м. Київ, Украӥна

Профілактика ферумдефіщитної анемії поросят є важливим превентивним заходом забезпечення здоров'я поголів'я свиней, оскільки летальність за даної патології є досить високою, а тварини, які одужують унаслідок лікування, не реалізовують власноі потенційної продуктивності. Метою нашої роботи було оцінити ефективність застосування клатрохелату Феруму (IV) у комбінації з ціанокобаламіном з метою профілактики ферумдефіцитної анемії поросят порівняно з традиційною схемою профілактики даної хвороби. Для виконання поставленої мети було сформовано 2 групи новонароджених поросят-аналогів у період їх утримання зі свиноматками на підсосі - контрольна та дослідна, по 15 тварин у кожній. Дослід тривав 30 діб. Поросята дослідної групи були відібрані від свиноматок, яким в період вагітності двічі внутрішньом'язово вводили по 10 мл 10 \% розчину клатрохелату Феруму 
(IV) та розчин иіанокобаламіну. Поросятам контрольної групи за традиційною схемою профілактики ферумдефіичтної анемії на другу добу життя вводили ферумодекстрановий препарат (з розрахунку 200 мг Феруму (III) на одне введення). Результати досліджень засвідчують, ще маса тіла поросят, народжених від свиноматок, яким у період вагітності застосовували клатрохелат Феруму (IV) та ціанокобаламін, за період від 1 до 9 доби життя була меншою від маси тіла поросят, яким на 2 добу після народження застосовували ферумодекстрановий препарат “Юніферон” ( $P<0,001)$; не відрізнялась на 12 добу життя, проте на 30 добу була більшою, ніж маса тіла поросят контрольної групи в 1,15 раза (P < 0,001). Рівень протеїну загального у сироватиі крові поросят дослідної групи від народження до 30 доби життя був вірогідно вищим, порівняно з контролем, щчо засвідчує, щчо клатрохелат Феруму (IV) стимулює синтез протеїнів в організмі. Отже, дворазова ін'єкція поросним свиноматкам 10 \% розчину клатрохелату Феруму (IV) в дозі 10 мл у комбінації з ін'єкціями ціанокобаламіну у дозі 500 мкг діючої речовини за 14 та 7 діб до передбачуваного опоросу забезпечує профілактичний ефект щуодо ферумдефіиитної анемії у народжених від них поросят.

Ключові слова: клатрохелат, ферум, анемія, поросята, свиноматки, маса тіла, протеїн.

\section{ВстуII}

У всьому світі за промислового вирощування свиней або приватного ведення свиногосподарства однією 3 найпоширеніших проблем $\epsilon$ ферумдефіцитна анемія поросят. За даної патології у хворих тварин знижуються середньодобові прирости, вони відстають у розвитку, збільшується сприйнятливість до інфекцій, а за тяжкого перебігу - зростає падіж поросят, який може досягати 60-70 \%. Хвороба спостерігається на 5-7 доби життя, а максимального розвитку досягає у тритижневому віці (Bonkovsky \& Herbert, 1991; Andreeva \& Serpkov, 2002; Karput' \& Nikoladze, 2003; Sidorkin et al., 2007; Killip \& Bennett, 2007; Zharov \& Zharov, 2012; Todoriuk et al., 2018; Martyshuk et al., 2019).

Згідно з літературними даними, перші спроби описати анемію датуються 1891 роком, але лише через 30 років було встановлено кореляцію між анемією поросят і дефіцитом Феруму в їхньому організмі. Спочатку для лікування хворих свиней та для профілатики ферумдефіцитної анемії застосовували лікарські форми на основі оксиду чи сульфату Феруму (II, III) в основному ентеральним шляхом за згодовування у складі корму. Згодом їх замінили препаратами для ін'єкцій з діючою речовиною декстран Феруму (III).

Основою сучасної профілактики ферумдефіцитної анемії $\epsilon$ внутрішньом'язове застосування ферумодекстранових препаратів поросятам упродовж першого тижня їхнього життя (Karput' \& Nikoladze, 2001; Batrakov et al., 2005; Levchenko et al., 2012). Важливе значення має саме профілактика, оскільки летальність за даної патології є досить висока, а після одужання у результаті лікування тварини не реалізовують власної потенційної продуктивності, а м'ясо втрачає поживні якості та відповідно має обмеження щодо реалізації (Andreeva \& Serpkov, 2002).

Виробництво таких препаратів в Україні не забезпечує достатньою мірою потреби в них, тому вітчизняний ринок ферумодекстранових ветеринарних препаратів представлений в основному імпортними лікарськими засобами (Kalynovska, 2014; Derkach, 2017). Зауважимо, що в нашій країні використовуються переважно не оригінальні препарати зарубіжних виробників, а їхні аналоги-дженерики (Havryliuk, 2005; Kotsiumbas et al., 2005). До того ж їх застосування призводить до збільшення собівартості власної продукції та зниження ії конкурентоспроможності (Vered, 2006), відтак спостерігається залежність від закордонного виробника (Melnychenko et al., 2014).
Хоча значну роботу в цьому напрямку вже проведено українськими вченими, розробка нових конкурентоспроможних вітчизняних протианемічних препаратів біометалів 3 метою їх високоефективного використання у практичній ветеринарній медицині залишається нині актуальним завданням.

Встановлено, що активність мікроелементів у сполуках з органічними речовинами підвищується в декілька разів порівняно з іонним станом, що забезпечує ефективнішу асиміляцію металів тваринами. Своєю чергою це дозволяє поряд з цілеспрямованим впливом на обмін речовин одержувати екологічно безпечну та високоякісну продукцію (Spears, 1989; Kravtsiv et al., 1997; Herasymenko et al., 2000; Dashkovskyi \& Vaseruk, 2003; Bilenchuk \& Kravtsiv, 2005; Kravtsiv et al., 2008).

Встановлено, що парентеральне введення поросятам-сисунам ферумодекстранових препаратів призводить до активації перекисного окислення ліпідів, що своєю чергою гальмує систему антиоксидантного захисту у тканинах поросят (Buchko et al., 1998). Для iii стимуляції застосовують ферумовмісні препарати у комбінації з Цинком та Селеном (Snitynskyi et al., 1998; Danchuk, 2013).

Нами раніше повідомлялося про результати доклінічних досліджень гострої та хронічної токсичності нової сполуки - клатрохелату Феруму у рідкісній валентності IV (Dukhnitsky et al., 2018; 2019). За клінічних досліджень даного комплексу вивчено його протианемічну ефективність в організмі поросят (Dukhnitsky et al., 2020). Нещодавно нами було запропоновано нову схему профілактики ферумдефіцитної анемії поросят на основі результатів дослідження протианемічної ефективності клатрохелату Феруму (IV) для поросят, народжених від свиноматок, яким застосовували препарат у період вагітності: дворазова ін'єкція поросним свиноматкам $10 \%$ розчину клатрохелату Феруму (IV) за 14 та 7 діб до передбачуваного опоросу забезпечувала профілактичний ефект щодо ферумдефіцитної анемії у народжених від них поросят (Dukhnitsky et al., 2020).

Останнім часом повідомляється про нові комплексні препарати, у яких поєднуються Ферум (III) 3 ціанокобаламіном та фолієвою кислотою. Зокрема виявляють більш позитивну різницю гематологічних показників у поросят, що отримували Ферум, вітаміни $\mathrm{B}_{12}$ та В9, ніж у поросят, яким застосовували Ферум (III) та ціанокобаламін, порівняно 3 контролем.

Як відомо, останній є антианемічним вітаміном, необхідним для нормального кровотворення, виявляє метаболічну, гемопоетичну функцію. В організмі 
(переважно в печінці) перетворюється у коферментну форму - аденозилкобаламін, або кобамамід, що $\epsilon$ активною формою вітаміну $\mathrm{B}_{12}$. Кобамамід сприяє дозріванню еритроцитів, бере участь у синтезі та накопиченні в еритроцитах сполук, які містять сульфгідрильні групи, що збільшує їхню толерантність до гемолізу. Активує систему згортання крові, у високих дозах спричиняє підвищення тромбопластичної активності та активності протромбіну, знижує рівень холестерину. Кобамамід входить до складу багатьох ензимів, у тому числі до складу редуктази, що відновлює фолієву кислоту в тетрафолієву; має високу біологічну активність. Кобамамід бере участь у перенесенні метильних та інших одновуглецевих фрагментів, тому він необхідний для синтезу дезоксирибози та ДНК, креатину, метіоніну, холіну тощо. Позитивно впливає на функцію печінки та нервової системи, а також підвищує здатність тканин до регенерації.

Наступним етапом наших досліджень $є$ вивчення нової схеми профілактики ферумдефіцитної анемії поросят, яка грунтується на застосуванні двох ін'єкційних препаратів - розчину клатрохелату Феруму (IV) та розчину ціанокобаламіну - не новонародженим поросятам, а свиноматкам у період вагітності.

\section{Матеріал і методи досліджень}

Для виконання поставленої мети було сформовано 2 групи новонароджених поросят-аналогів (гібриди порід ландрас та велика біла) у період їхнього утримання зі свиноматками на підсосі - контрольна та дослідна, по 15 тварин у кожній.

У дослідну групу були відібрані поросята від 5 свиноматок (по 3 від кожної), яким в період вагітності двічі (за 14 та 7 діб до очікуваного опоросу) внутрішньом'язово вводили по 10 мл $10 \%$ розчину клатрохелату Феруму (IV) та розчин ціанокобаламіну (у дозі для свиноматок, рекомендованій офіційними інструкціями, - з розрахунку по 500 мкг діючої речовини на одне введення).

Поросятам контрольної групи за традиційною схемою профілактики ферумдефіцитної анемії на другу добу життя вводили ферумодекстрановий препарат "Юніферон” у дозі 1 мл для тварини (200 мг Феруму(III) на одне введення).

Діючою речовиною препарату, що застосовували свиноматкам, $є$ Ферум у рідкісній валентності IV та у формі клатрохелату - це макробіциклічний комплекс, у якому іон металу “упакований” у нанокапсулу, яка перешкоджає взаємодії з переважною більшістю реагентів, зокрема біолігандами, а також екранує метал від інших факторів навколишнього середовища. Вперше про синтез унікальних клатрохелатних сполук Феруму (IV) було повідомлено Tomyn et al. (2017). Ми провели ряд доклінічних досліджень їх гострої та хронічної токсичності, кумулятивних властивостей та клінічних досліджень (Dukhnitsky et al., 2018; 2019; 2020).
Для розчинення порошку клатрохелату Феруму (IV) нами був використаний розчинник реополіглюкін, що є плазмозамінним колоїдним розчином декстрану (полімеру глюкози), містить, окрім декстрану, натрію хлорид та воду для ін'єкцій.

Протягом 1 місяця за поросятами вели спостереження, зважували на 1, 5, 9, 12 та 30 доби після народження та визначали динаміку змін маси тіла поросят контрольної та дослідної груп; для досліджень вмісту загального протеїну в сироватці крові поросят відбирали зразки крові на 1, 5, 12 та 30 доби життя.

\section{Результати та їх обговорення}

Упродовж науково-виробничого досліду, який тривав 30 діб, особливу увагу було зосереджено на клінічних ознаках, що характеризують прояв анемії, зокрема у поросят дослідної групи, оскільки акцентувалося на вивченні нової схеми профілактики даної патології - впливу клатрохелату Феруму (IV) у комбінації з цінкобаламіном, введених у період вагітності поросним свиноматкам, на подальший розвиток молодняку свиней.

У результаті проведених досліджень не було виявлено народження мертвих поросят та не спостерігалось будь-яких клінічних ознак анемії. Нами не відмічалося блідості слизових оболонок (з жовтуватим відтінком), скуйовдженості щетини, сухості чи зморщення шкіри поросят. Також не спостерігалося прискорення пульсу та ритму дихання у них, що відповідно $є$ характерним для прояву анемії. У всіх поросят за період досліду не виявляли відставання у рості, розладів травлення чи малорухливості. Побічних реакцій на введення препаратів не виявлено.

Поросята активно ссали свиноматок, природно займали соски з більшим рівнем лактації молочних пакетів, що відповідно впливало на збільшення маси їхьої тіла. Варто зазначити, що поросята дослідної групи були більш активними, ніж поросята контрольної групи, що підтверджує дані Приступи Т. I. зі спіавт. (2013), які доводять, що вміст Феруму в організмі поросят-сисунів впливає на зниження рухливості та тривалість ссання молока свиноматки.

Зміни маси тіла дослідних тварин, порівняно 3 контролем, $є$ дуже вагомим показником, порушення якого свідчить про ступінь неблагополуччя в організмі. Зміни маси тіла особливо важливі для молодих підростаючих тварин; зі збільшенням віку приріст маси відбуваєтся значно повільніше (Kocjumbas, 2006).

Вже на першу добу життя нами спостерігалася різниця у масі тіла поросят контрольної та дослідної груп (табл. 1). Поросята, народжені від свиноматок, яким у період вагітності вводили розчин клатрохелату Феруму (IV) та розчин ціанокобаламіну, мали вірогідно меншу в 1,4 раза $(\mathrm{P}<0,001)$ вагу порівняно 3 контролем. 
Таблиця 1

Маса тіла піддослідних поросят, г $(\mathrm{M} \pm \mathrm{m}, \mathrm{n}=15)$

\begin{tabular}{ccc}
\hline \multirow{2}{*}{ Вік поросят, діб } & \multicolumn{2}{c}{ Група поросят } \\
\cline { 2 - 3 } & І контрольна & II дослідна \\
\hline 1 & $1760,3 \pm 15,44$ & $1295,3 \pm 31,39^{* * *}$ \\
9 & $2760,7 \pm 90,58$ & $1899,9 \pm 20,19^{* * *}$ \\
12 & $3103,9 \pm 68,19$ & $2560,9 \pm 97,19^{* * *}$ \\
30 & $3579,4 \pm 58,73$ & $3358,0 \pm 133,82$ \\
& $7456,7 \pm 94,32$ & $8543,2 \pm 150,13^{* * *}$ \\
\hline
\end{tabular}

Примітка: ступінь вірогідності - * - $\mathrm{P}<0,05, * *-\mathrm{P}<0,01, * * *-\mathrm{P}<0,001$; порівняно з показником у поросят контрольної групи

На п’яту добу маса тіла поросят дослідної групи була в 1,5 раза вірогідно меншою $(\mathrm{P}<0,001)$, ніж маса тіла поросят контрольної групи. Варто зазначити, що на другу добу життя поросятам контрольної групи було введено традиційний ферумодекстрановий препарат, що забезпечував вплив на обмін речовин та загальний стан організму тварин.

На 9 та 12 добу різниця у масі тіла поросят дослідної та контрольної груп ставала менш вираженою. На 9 добу життя маса тіла поросят дослідної групи була в 1,2 раза вірогідно меншою $(\mathrm{P}<0,001)$ порівняно 3 контролем, а на 12 добу майже не відрізнялася від контролю.

За період від 12 до 30 доби життя маса тіла поросят дослідної групи зростала інтенсивніше, ніж маса тіла поросят контрольної групи, і на 30 добу була вірогідно більшою в 1,15 раза $(\mathrm{P}<0,001)$ порівняно 3 контролем.

Загальновідомо, що білки в обміні речовин мають особливе значення. Обмін білків координує, регулює та інтегрує більшість хімічних перетворень, а також $є$ важливою ланкою, відповідальною за гомеостаз, адже внутрішньоклітинна відповідь на дію екзогенних чинників здійснюється за участю протеїнів (Kocjumbas, 2006). Вміст протеїну загального у сироватці крові характеризує ступінь реактивності, дозволяє оцінити стан обміну протеїнів і рівень їхнього синтезу в організмі (табл. 2).

Як відомо, ферумдефіцитна анемія поросят розвивається не тільки за дефіциту Феруму та речовин, що стимулюють гемопоез Купруму, Кобальту, Марганцю, вітамінів $\mathrm{B}_{6}, \mathrm{~B}_{12}$ тощо, а й нестачі протеїну в кормах. За розвитку даної патології знижується показник загального протеїну в сироватці крові хворих тварин. Це має важливе значення, оскільки білки відіграють головну роль в підтримці в'язкості крові, формуванню та утриманні відповідного об'єму формених елементів крові; забезпечують зв'язування та транспортування гормонів, вітамінів, мінеральних речовин та ліпідів в організмі. Згідно з даними Коцюмбаса I. Я. (Kocjumbas, 2006), на підставі вивчення протеїнового спектру оцінюють білоксинтезувальну функцію печінки. Ступінь вираженості гіпопротеїнемії $є$ показником тяжкості перебігу процесу в печінці.

\section{Таблиця 2}

Динаміка вмісту протеїну загального в сироватці крові поросят за дії ферумовмісних препаратів $(\mathrm{M} \pm \mathrm{m}, \mathrm{n}=15)$

\begin{tabular}{ccl}
\hline \multirow{2}{*}{ Вік поросят, діб } & \multicolumn{3}{c}{ Група поросят } \\
\cline { 2 - 3 } & I контрольна & II дослідна \\
\hline 1 & $21,6 \pm 0,32$ & $25,7 \pm 0,25^{* * *}$ \\
12 & $44,9 \pm 0,32$ & $45,4 \pm 1,77$ \\
30 & $43,9 \pm 0,51$ & $47,4 \pm 0,97^{*}$ \\
& $47,4 \pm 0,32$ & $51,3 \pm 0,20^{* * *}$ \\
\hline
\end{tabular}

Примітка: ступінь вірогідності - * - $\mathrm{P}<0,05, * *-\mathrm{P}<0,01, * * *-\mathrm{P}<0,001$; порівняно 3 показником у поросят контрольної групи

Результати досліджень, подані в таблиці 2, підтверджують, що клатрохелат Феруму (IV) стимулює синтез протеїнів в організмі. Так, рівень протеїну загального у сироватці крові поросят дослідної групи вже від народження та упродовж 30 діб життя був вірогідно вищим, ніж у контролі. Так, на 1 добу життя даний показник у сироватці крові поросят дослідної групи був вищим відповідно у 1,19 раза, ніж у сироватці крові поросят контрольної групи; на 5 добу майже не відрізнявся, а на 12 та 30 добу в 1,08 раза вищим порівняно з контролем (табл. 2).

Варто зауважити, що значення умісту протеїну загального в сироватці крові поросят обох груп були в межах фізіологічних коливань протягом усього періоду досліджень.

\section{Висновки}

1. Дворазова ін'єкція поросним свиноматкам 10 \% розчину клатрохелату Феруму (IV) в дозі 10 мл у комбінації з ін'єкціями ціанокобаламіну в дозі 500 мкг діючою речовини за 14 та 7 діб до передбачуваного опоросу забезпечує профілактичний ефект щодо ферумдефіцитної анемії у народжених від них поросят.

2. Маса тіла поросят, народжених від свиноматок, яким у період вагітності застосовували клатрохелат Феруму (IV) та ціанокобаламін, за період від 1 до 9 доби життя була меншою від маси тіла поросят, яким на 2 добу після народження застосовували ферумодекстрановий препарат "Юніферон” (Р < 
0,001); не відрізнялась на 12 добу життя, проте на 30 добу була більшою, ніж маса тіла поросят контрольної групи в 1,15 раза $(\mathrm{P}<0,001)$.

3. Рівень протеїну загального у сироватці крові поросят дослідної групи від народження до 30 доби життя був вірогідно вищим порівняно 3 контролем, що засвідчує, що клатрохелат Феруму (IV) стимулює синтез протеїнів в організмі.

\section{References}

Andreeva, A., \& Serpkov, A. (2002). Kak predotvratit' alimentarnuju anemiju porosjat. Zhivotnovodstva, 2, 87 (in Russian).

Batrakov, A., Travkin, O., \& Jakovleva, E. (2005). Profilaktika alimentarnoj anemii u porosjat. Veterinarija, 12, 44-45 (in Russian).

Bilenchuk, R. V., \& Kravtsiv, R. I. (2005). Aktyvnist transaminaz syrovatky krovi koriv pid vplyvom dobavok defitsytnykh mikroelementiv. Eksperymentalna ta klinichna fiziolohiia, 2, 254-256 (in Ukrainian).

Bonkovsky, S., \& Herbert, L. (1991). Iron and the Liver. The American journal of the medical sciences, 301(1), 32-43. doi: 10.1097/00000441-199101000-00006.

Buchko, O. M., Snitynskyi, V. V., Danchuk, V. V., \& Antoniak H. L. (1998). Zastosuvanna spoluk selenu dlia profilaktyky oksydatsiinoho stresu u porosiat rannoho viku. Haukovyi visnyk Hatsionalnoho Ahrarnoho universytetu, 10, 156-163 (in Ukrainian).

Danchuk, O. V. (2013). Peroksydne okysnennia lipidiv ta aktyvnist systemy antyoksydantnoho zakhystu u porosiat-sysuniv pid vplyvom preparativ zaliza. Svynarstvo, 62, 89-93 (in Ukrainian).

Dashkovskyi, O., \& Vaseruk, N. (2003). Dynamika bilkovoho obminu u syrovattsi krovi diinykh koriv za dii metionativ zaliza, midi, vitaminu $\mathrm{E}$ ta svyntsiu. Naukovyj visnyk Lvivskogo nacionalnogo universytetu veterynarnoi medycyny ta biotehnologij imeni S. Z Gzhyckogo, 5(2), 10-13.

Derkach, I. (2017). Suchasni tendencii' na vitchyznjanomu rynku ferumvmisnyh preparativ dlja tvaryn. Scientific Messenger of LNU of Veterinary Medicine and Biotechnologies. Series: Veterinary Sciences, 19(78), 23-25. doi: 10.15421/nvlvet7805 (in Ukrainian).

Dukhnitsky, V. B., Derkach, I. M., Plutenko, M. O., Fritsky, I. O., \& Derkach, S. S. (2018). Determination of the accumulative toxicity parameters of iron (IV) on white mice. Ukrainian Journal of Ecology, 8(2), 308-312. doi: $10.15421 / 2018343$.

Dukhnitsky, V., Derkach, I., Derkach, S., Fritsky, I., \& Plutenko, M. (2019). Chronic toxicity of the Iron (IV) clathrochelate complexes for white rats. Scientific Messenger of LNU of Veterinary Medicine and Biotechnologies. Series: Veterinary Sciences, 21(95), 1521. doi: $10.32718 /$ nvlvet9503.

Dukhnitsky, V. B., Derkach, I. M., Plutenko, M. O., Fritsky, I. O., \& Derkach, S. S. (2019). Cumulative properties of Iron(IV) clathrochelate in rats [Kumuliatyvni vlastvosti klatrokhelatu Ferumu (IV) dlia bilykh shchuriv]. Visnyk PDAA, 2, 238-246. doi: 10.31210/visnyk2019.02.32 (in Ukrainian).
Dukhnitsky, V., Derkach, I., Plutenko, M., Fritsky, I., \& Derkach, S. (2019). Acute toxicity of the iron clathrochelate complexes. Regulatory Mechanisms in Biosystems, 10(3), 276-279. doi: 10.15421/021942.

Dukhnitsky, V. B., Derkach, I. M., Derkach, S. S., Plutenko, M. O., \& Fritsky, I. O. (2019). Influence of iron (IV) clathrochelate complex on quail blood parameters and weight characteristics. Ukrainian Journal of Ecology, 9(3), 126-131. doi: 10.15421/2019_719.

Dukhnitsky, V., Derkach, I., Derkach, S., Fritsky, I., \& Plutenko, M. (2020). Investigations of the irritant effect and allergenic properties of Fermat's clatrochelate (IV). Scientific Messenger of LNU of Veterinary Medicine and Biotechnologies. Series: Veterinary Sciences, 22(97), 130-135. doi: 10.32718/nvlvet9721.

Dukhnitsky, V., Derkach, I., Derkach, S., Fritsky, I., \& Plutenko, M. (2020). Study of the antianemic effect of iron (IV) clatrochelate on piglets. Scientific Messenger of LNU of Veterinary Medicine and Biotechnologies. Series: Veterinary Sciences, 22(99), 107-115. doi: 10.32718/nvlvet9917.

Dukhnitsky, V. B., Kalachniuk L. H., Derkach, I. M., Derkach, S. S., Plutenko, M. O. \& Fritsky, I. O. (2020). Iron(IV) hexahydrazide clathrochelate complexes: the chronic toxicity study. Ukrainian Journal of Ecology, 9(3), 18-23. doi: 10.15421/2020 3.

Herasymenko, V., Bitiutskyi, V., \& Melnychenko, O. (2000). Fizyko-khimichni osnovy konstruiuvannia metaloorhanichnykh spoluk. Visnyk Bilotserkivskoho derzhavnoho ahrarnoho universytetu, 11, 149-152 (in Ukrainian).

Havryliuk, O. H. (2005). Konkurentsiia na vitchyznianomu rynku veterynarnykh preparativ. Aktualni problemy ekonomiky, 8, 49-55 (in Ukrainian).

Kalynovska, L. (2014). Zareiestrovani v Ukraini preparaty dlia profilaktyky i likuvannia tvaryn pry anemii. Naukovyi biulleten Instytutu veterynarnoi medytsyny, 15, 279-283 (in Ukrainian).

Karput', I. M., \& Nikoladze, M. G. (2001). Diagnostika i profilaktika alimentarnoj anemii porosjat. Veterinarija, 4, 34-37 (in Russian).

Karput' I. M., \& Nikoladze M. G. (2003). Obmen zheleza u zdorovyh i bol'nyh alimentarnoj anemiej porosjat. Bulletin of the Academy of Agrarian Sciences of the Republic of Belarus, 4, 34-37 (in Russian).

Killip, S., \& Bennett, M. (2007). Iron Deficiency Anemia. American Family Physician, 75(5), 671-678.

Kotsiumbas, I., Havryliuk, O., \& Tesliar, H. (2005). Innovatsiina diialnist ta rozrobka novykh veterynarnykh preparativ dlia rynku Ukrainy. Naukovo-tekhnichnyi biuleten Instytutu biolohii tvaryn i Derzhavnoho naukovo-doslidnoho instytutu vetpreparativ ta kormovykh dobavok, 3,4, 188-196 (in Ukrainian).

Kocjumbas, I. J. (2006). Doklinichni doslidzhennja veterynarnyh likars'kyh zasobiv. L'viv: Triada pljus (in Ukrainian).

Kravtsiv, R. I. Novykov, V. P., \& Stadnyk, A. M. (1997). Khelatni kompleksy mikroelementiv / Metionaty /: syntez, biolohichna diia, produktyvnist khudoby i ptytsi. Suchasni problemy biolohii, veterynarnoi 
medytsyny, zooinzhenerii ta tekhnolohii produktiv tvarynnytstva, 330-333 (in Ukrainian).

Kravtsiv, R. I., Oseredchuk, R. S., Bilenchuk, R. V., Kliuchkovska, M. V., Herych, V. V., \& Senechyn, V. V. (2008). Vplyv khelatnykh spoluk mikroelementiv na produktyvnist velykoi rohatoi khudoby ta biolohichnu i kharchovu tsinnist yikh produktsii. Silskyi hospodar, 11-12, 1-3 (in Ukrainian).

Levchenko, V. I., Kondrakhin, I. P., \& Vlizlo, V. V. (2012). Vnutrishni khvoroby tvaryn. Chastyna 1. Bila Tserkva (in Ukrainian).

Martyshuk, T., Gutyj, B., Vishchur, O., \& Todoriuk, V. (2019). Biochemical indices of piglets blood under the action of feed additive "Butaselmevit-plus". Ukrainian Journal of Veterinary and Agricultural Sciences, 2(2), 27-30. doi: 10.32718/ujvas2-2.06.

Melnychenko, O. M., Vered, P. I., \& Kharchyshyn, V. M. (2014). Profilaktyka alimentarnoi anemii porosiat vitchyznianymy ta importnymy antyanemichnymy preparatamy. Tekhnolohiia vyrobnytstva i pererobky, 2, 10-14 (in Ukrainian).

Sidorkin, V., Gavrish, V., Egunova, A., \& Ubiraev, V. (2007). Bolezni svinej. Akvarium - print, Moskwa (in Russian).

Snitynskyi, V. V., Danchuk, V. V., \& Buchko, O. M. (1998). Aktyvnist antyoksydantnykh fermentiv ta intensyvnist protsesiv vilnoradykalnoho okyslennia $\mathrm{u}$ tkanynakh svynei u period postnatalnoi adaptatsii. Ukrainskyi biokhimichnyi zhurnal, 70, 105-110 (in Ukrainian).

Spears, J. W. (1989). Zinc Methionine for Ruminants: Relative Bioavailability of Zinc in Lambs and Effects of Growth and Performance of Growing Heifers. Journal of Animal Science, 67, 835-843. doi: 10.2527/jas1989.673835x.

Todoriuk, V. B., Hunchak, V. M., Gutyj, B. V., Gufriy, D. F., Hariv, I. I., Khomyk, R. I., \& Vasiv, R. O. (2018). Preclinical research of the experimental preparation "Ferosel T". Ukrainian Journal of Veterinary and Agricultural Sciences, 1(1), 3-9. doi: 10.32718/ujvas1-1.01.

Tomyn, S., Shylin, S. I., Bykov, D., Ksenofontov, V., Gumienna-Kontecka, E., Bon, V., \& Fritsky, I. O. (2017) Indefinitely stable iron (IV) cage complexes formed in water by air oxidation. Nature Communications, $8,1-8$.

Vered, P. I. (2003). Vyvchennia dii proty anemichnykh preparativ vitchyznianoho vyrobnytstva na orhanizm porosiat. Zbirnyk materialiv III mizhvuzivskoi naukovo-praktychnoi konferentsii aspirantiv "Suchasna ahrarna nauka: napriamy doslidzhen, stan i perspektyvy". Vinnytsia, 222-223 (in Ukrainian).

Zharov, A. V., \& Zharov, Ju. P. (2012). Patologija obmena veshhestv $\mathrm{u}$ vysokoproduktivnyh zhivotnyh. Veterinarija, 9, 46-50 (in Russian). 